\title{
BACTERIOLOGICAL ASSESSMENT OF DRINKING WATER OF RAWALAKOT DISTRICT, AZAD KASHMIR, PAKISTAN
}

\author{
Syed Waasif Shoukat', Said Akbar Khan', \\ Muhammad Ishtiaq ${ }^{2}$, Inayat Shah', \\ Syed Umair Ullah Jamil', Tahseenullah Khan'
}

\begin{abstract}
OBJECTIVE: To assess the bacteriological quality of drinking water sources in District Rawalakot, Azad Kashmir, Pakistan.

METHODS: After approval from the Ethical Review Committee of Bahria University Islamabad; this cross-sectional descriptive study was conducted in Rawalakot District from September 2017 to March 2018. Out of 90 samples, 45 samples ( 15 each from bore-well, open-well \& spring water) were collected in September \& October 2017 as pre-rainfall season's samples and 45 samples were collected in post-rainfall season of February \& March 2018, exactly from the same 45 sites from which pre-rainfall water samples were collected. All the samples were analyzed for total bacterial, total coliforms, Escherichia Coli, Shigella and Salmonella Species.
\end{abstract}

RESULTS: Overall bacterial growth on Nutrient Agar was more commonly observed in samples from Bore-well $(n=11 / 15 ; 73.33 \%)$ during pre-rainfall season and in open-well samples $(n=12 / 15 ; 80 \%)$ during post-rainfall season. Total coliforms growth on MacConkey agar was more frequent in post- rainfall season in samples from spring-water $(n=9 / 15 ; 60 \%)$. On eosin methyl blue agar, majority ( $n=5 / 15 ; 33.33 \%$ ) of Escherichia Coli growth was observed during post-rainfall season in spring water samples. Almost all of the post-rainfall season samples revealed less number of Shigella and Salmonella species compared to pre-rainfall water samples.

CONCLUSION: The post-rainfall season drinking water samples of bore wells, open wells and spring water showed higher number of bacteriological contaminations except Shigella and Salmonella species which were reduced in post-rainfall samples of bore-wells and revealed equal numbers among openwells and spring water samples.

KEY WORDS: Drinking Water (MeSH); Springs (MeSH); Bacteriological (MeSH); Escherichia Coli (MeSH); Salmonella (MeSH); Shigella (MeSH).

THIS ARTICLE MAY BE CITED AS: Shoukat SW, Khan SA, Ishtiaq M, Shah I, Jamil SUU, Khan T. Bacteriological assessment of drinking water of Rawalakot district, Azad Kashmir, Pakistan. Khyber Med Univ J 20I9; I (4):222-5. DOI: I0.35845/kmuj.20I9.18799

\section{INTRODUCTION}

W ater is considered as one of the most important element on earth surface, maintaining life. Water has covered approximately $70 \%$ of the Earth's surface but the fresh water supply is of great concern in the developing and developed countries.'
According to World Health Organization report, globally approximately 1.2 billion people are without safe drinking water; and mostly affecting the people of sub-Saharan Africa, South Asia and East Asia. Bacteriological contaminations are reckoned as one of the most threatening problem of drinking and is a major cause of water-borne disease i.e.
I. Department of Earth and Environmental Sciences, Bahria University, Islamabad Campus, Islamabad, Pakistan.

2. Department of Community Medicine, Northwest School of Medicine Hayatabad Peshawar, Pakistan

3. Institute of Basic Medical Sciences, Khyber Medical University, Peshawar, Pakistan. Email『: drishtiaq250@yahoo.com Contact\#: +92-3349121822

$\begin{array}{ll}\text { Date Submitted: } & \text { November 18, 2018 } \\ \text { Date Revised: } & \text { November 29, 2019 } \\ \text { Date Accepted: } & \text { December 03, 2019 }\end{array}$

gastroenteritis, diarrhea, dysentery, typhoid, hepatitis $A$ \& $E$ and other health related issues. ${ }^{3,4}$

In many international and national studies, each year approximately 0.5 million children die due to diarrheal diseases. 5,6 Moreover, according to research studies, in developing countries approximately 1.8 million children died from biological agents of water and food in year 1998..$^{6-8}$ Inefficient sewage system and improper sanitation barriers, direct discharge of waste into the natural reservoirs and water bodies, are considered as the major source of fecal contamination of water.' Generally, it is believed that pathogenic bacteria for example Escherichia coli, Thermo-tolerant coliforms, total coliforms, fecal streptococci and Clostridium perfringens, parasites and viruses can contaminate quality of drinking water. Most probable sources of these contaminants in water can be fecal matter, agriculture runoff and domestic waste, urban and pasture runoff. ${ }^{10,1}$

In Pakistan, both surface and ground sources of drinking water are polluted with coliforms, toxic metals and pesticides and it is ranked at number I 18 among 190 countries regarding the quality of drinking water. ${ }^{12,13}$ Usually, the bacteriological assessment of drinking water is carried out to check the presence of total and fecal coliforms. Coliforms are generally found in the environment and are usually harmless to human beings but their presence in water is used as sign of water polluted with disease causing agents. The presence of Escherichia coli and fecal coliforms in water suggests that water is 
TABLE I: RESULTS OF PRE \& POST- RAINFALL WATER SAMPLES SOURCES OF BORE WELLS, OPEN WELLS \& SPRING WATER $(n=90)$

\begin{tabular}{|l|c|c|c|c|c|c|}
\hline & \multicolumn{3}{|c|}{ Pre-rainfall season } & \multicolumn{2}{c|}{ Post-rainfall season } \\
\cline { 2 - 7 } & $\begin{array}{c}\text { Bore } \\
\text { well } \\
(n=15)\end{array}$ & $\begin{array}{c}\text { Open } \\
\text { well } \\
(n=15)\end{array}$ & $\begin{array}{c}\text { Spring } \\
\text { water } \\
(n=15)\end{array}$ & $\begin{array}{c}\text { Bore } \\
\text { well } \\
(n=15)\end{array}$ & $\begin{array}{c}\text { Open } \\
\text { well } \\
(n=15)\end{array}$ & $\begin{array}{c}\text { Spring } \\
\text { water } \\
(n=15)\end{array}$ \\
\hline Nutrient Agar $\left(10^{7}\right)$ & $\begin{array}{c}\mathrm{II} \\
(73.33 \%)\end{array}$ & $\begin{array}{c}(60 \%) \\
(40 \%)\end{array}$ & $\begin{array}{c}6 \\
(46.67 \%)\end{array}$ & $\begin{array}{c}12 \\
(80 \%)\end{array}$ & $\begin{array}{c}9 \\
(60 \%)\end{array}$ \\
\hline MacConkey Agar $\left(10^{7}\right)$ & 5 & $\mathrm{I}$ & 3 & 6 & 8 & 9 \\
& $(33.33 \%)$ & $(6.67 \%)$ & $(20 \%)$ & $(40 \%)$ & $(53.3 \%)$ & $(60 \%)$ \\
\hline Eosin Methyl Blue & 2 & 0 & $\mathrm{I}$ & 3 & 3 & 5 \\
Agar $\left(10^{7}\right)$ & $(13.33 \%)$ & $(0 \%)$ & $(6.67 \%)$ & $(20.00 \%)$ & $(20 \%)$ & $(33.33 \%)$ \\
\hline Salmonella and & 6 & $\mathrm{I}$ & $\mathrm{I}$ & 0 & 0 & $\mathrm{I}$ \\
Shigella Agar $\left(10^{7}\right)$ & $(40 \%)$ & $(6.67 \%)$ & $(6.67 \%)$ & $(0 \%)$ & $(0 \%)$ & $(6.67 \%)$ \\
\hline
\end{tabular}

Pre Rainfall Season: September \& October Samples; Post Rainfall Season: February \& March Samples

contaminated with animals or human waste. $^{14}$

Pakistan being a developing country and thus have high burden of communicable and non-communicable diseases. Moreover, most of the water sources in Pakistan i.e. rivers, lakes, tube-wells, dug-wells and ground water aquifers are highly contaminated with bacteria, therefore this cross-sectional study was carried out in the nearby villages of District Rawalakot, Azad Kashmir, Pakistan; to assess the bacteriological assessment of drinking water resources; and to communicate findings to the local communities and concerned departments, for relevant measures to reduce the burden of water borne diseases.

\section{METHODS}

After taking approval from the Ethical Review Committee of Bahria University Islamabad, Pakistan, a cross-sectional descriptive study was carried out, from September 2017 to March 2018, in the Rawalakot District, Azad Kashmir, Pakistan.

In this study, a total of ninety samples (30 each from bore well, open well \& spring water) were collected through convenience technique from the drinking water sources and were analyzed for bacteriological assessment. Out of 90 samples, 45 samples ( 15 each from bore well, open well \& spring water) were collected in September \& October 2017 as pre-rainfall seasons samples and 45 samples were collected in post rainfall season of February \&
March 2018, exactly from the same 45 sites from which pre-rainfall water samples were collected. Almost all of the drinking water sources used by the local communities of District Rawalakot were included in the sampling frame i.e. bore-wells, open-wells and spring water; and were analyzed for bacteriological assessment. The bacterial analysis of the drinking water samples were carried out by plate count method; and thus on Nutrient-Agar showed the total bacterial load, Eosin Methyl Blue Agar showed Escherichia coli, SS-Agar showed presence of Salmonella and Shigella whereas Mac Conkey agar showed growth of total coliforms in the collected drinking water samples. Finally a total of 360 parameters were assessed via four different plate counts in the pre- and post-rainfall water samples. Finally the data was analyzed and presented in form of tables against the qualitative water sources variables of bore-wells, open-wells and spring water.

\section{RESULTS}

During pre-rainfall season, samples from bore-wells showed total bacterial count on Nutrient Agar in II (73.33\%) cases and isolation of Salmonella and Shigella in $6(40 \%)$ samples (Table I). Similarly, the water samples from openwell and spring water showed bacterial growth on nutrient agar in nine $(60 \%)$ and six $(40 \%)$ samples respectively.

During post-rainfall season, water samples from bore-wells showed total bacterial load on Nutrient Agar in 7 $(46.67 \%)$ samples and growth of total coliforms on MacConkey agar in 6 $(40 \%)$ samples. While in samples from open-well revealed total bacterial count in $12(80 \%)$ samples and total coliforms on MacConkey agar in 8 (53.3\%) samples. Spring water samples in postrainfall season showed total bacterial count and total coliforms in $9(60 \%)$ samples each on Nutrient agar and MacConkey agar respectively.

Overall bacterial growth on Nutrient Agar was more commonly observed in samples from Bore-well $(n=11 / 15$; $73.33 \%$ ) during pre-rainfall season and in open-well samples $(n=12 / 15 ; 80 \%)$ during post- rainfall season. Total coliforms growth on MacConkey agar was more frequent in post- rainfall season in samples from spring-water $(n=9 / 15 ; 60 \%)$. Majority $(n=5 / 15$; $33.33 \%$ ) of $E$. Coli growth on eosin methyl blue agar, was observed during post-rainfall season in spring water samples. Almost all of the post-rainfall season samples revealed less number of Shigella and Salmonella species compared to pre-rainfall water samples.

\section{DISCUSSION}

Among the bore-well water samples; in pre-rainfall seasons $n=11(73.3 \%)$ showed total bacterial count (TBC) and $n=5(33.33 \%)$ showed total Coliforms. Moreover, only $n=2(13.33 \%)$ showed E.Coli and $n=7$ (46.67\%) showed Salmonella \& Shigella (SS). In postrainfall seasons, $n=7$ (46.67\%) showed TBC, $n=6(40 \%)$ showed total Coliforms and none of the samples showed SS. Many international studies found increased numbers of Coli, total coliforms, fecal coliforms, Shigella and Salmonella species in post-rainfall samples. ${ }^{1,15,16}$ Moreover, many studies revealed that increased prevalence of water borne diseases was due to increased number of total bacterial count and total coliforms as was confirmed by our study results of postrainfall water samples. ${ }^{17,18}$

In open-well pre-rainfall samples; $\mathrm{n}=9$ $(60 \%)$ showed total coliforms whereas in post-rainfall $n=12(80 \%)$ were found positive; in pre-rainfall samples, $\mathrm{n}=\mathrm{I}$ (6.67\%; OWI0) while $n=8$ (53.33\%) showed total coliforms in post-rainfall samples. Moreover, in none of the pre- 
rainfall samples showed E.Coli whereas $\mathrm{n}=3(20 \%)$ showed E. Coli in postrainfall samples. Approximately $6.67 \%$ $(n=I$; OW7) showed SS in pre-rainfall samples whereas in none of the postrainfall water samples revealed SS. Furthermore, many international studies revealed that numbers of E.Coli and TBC increased after rainfall ${ }^{19,20}$ as was confirmed in this study among the open-wells water samples. Interestingly, in a study conducted by Hsu TT showed reduced levels of E. Coli and $T B C$ after rainfall and thus these findings were consistent to this study in which Salmonella and Shigella were in less number in pre-rainfall samples of Bore-wells and open-wells. ${ }^{21}$ Many international studies; also revealed that microbial contamination was lesser in post-rainfall water samples. ${ }^{22,23}$ Although the findings of the above study was contradictory to the results of open well and spring water samples whereas findings of bore-well supported the international studies findings.

In a study conducted by Onuoha SC in Nigeria; found that $23.1 \%$ showed positive results for E.Coli, II.5\% for Shigella; and $3.8 \%$ for Salmonella. ${ }^{24}$ In spring, pre-rainfall water samples; $n=6$ (40\%) showed TBC, $n=3(20 \%)$ showed Total Coliforms and only one $(n=I ; 6.67 \%)$ showed E.Coli; and Salmonella \& Shigella species in SI \& S3. In post-rainfall water samples; $\mathrm{n}=9$ (60\%) showed TBC, $n=5$ (33.33\%) showed E.Coli and only one (6.67\%; nS6) showed Salmonella \& Shigella (Table I). Furthermore, in an international study, conducted by Sadik NJ, et al., in 2017; showed that E.Coli, Shigella and salmonella were present both in the pre-rainfall and post-rainfall water samples. ${ }^{25}$

From this study it was recommended that drinking water sources be protected from the man-made factors resulting in contamination. Moreover, the community needs to be educated; and appropriate measures to be adopted by the concerned departments to reduce the man-made factors in addition to the natural causes of bacteriological contamination of drinking water sources of District Rawalakot, Azad Kashmir Pakistan.

\section{CONCLUSION}

From this study, it was concluded that the post-rainfall season drinking water samples of bore-wells, open-wells and spring water showed higher number of bacteriological contaminations except Shigella and Salmonella species which were reduced in post-rainfall samples of bore-wells open wells, and also among the pre-rainfall water samples of bore wells which showed higher concentration of total bacterial count as compared to post-rainfall water samples. Moreover, the Shigella and Salmonella species also revealed equal numbers among open-wells and spring water samples.

\section{REFERENCES}

I. Nawab J, Khan S, Ali S, Sher H, Rahman Z, Khan K, et al. Health risk assessment of heavy metals and bacterial contamination in drinking water sources: a case study of Malakand Agency, Pakistan. Env Monit Assess 2016 May I;188(5): 286. DOI: 10.1007/s 1066I-0165296-I.

2. Ashbolt NJ. Microbial contamination of drinking water and human health from community water systems. Curr Environ Health Rep 2015 Mar I;2(I):95- I06. DOI: 10.1007/s40572-0I4-0037-5.

3. Khan S, Shahnaz M, Jehan N, Rehman S, Shah MT, Din I. Drinking water quality and human health risk in Charsadda district, Pakistan. J Clean Prod 2013 Dec 1;60:93-101. DOI: 10.1016/j.jclepro.2012.02. 016.

4. Sarker S, Mahmud S, Sultana R, Biswas R, Sarkar PP, Munayem MA, et al. Quality Assessment of Surface and Drinking Water of Nakla Paurosova, Sherpur, Bangladesh. Adv Microb 2019 Aug 9;9(8):703. DOI: 10.4236/aim.2019.98043.

5. Shar AH, Kazi YF, Zardari M, Soomro IH. Enumeration of total and fecal coliform bacteria in drinking water of Khairpur Sindh. Bangladesh J Microbiol 2007; 24(2):|63-5. DOI: 10.3329| bjm.v24i2.1266.
6. Rahman S, Anoar KP, Rezwanul I. Identification and quantification of Escherichia coli from drinking water in Bangladesh. Int J Microb Immun Res 20I3; I (4):47-5I.

7. Akbar A, Anal AK. Food safety concerns and food-borne pathogens, Salmonella, Escherichia coli and Campylobacter. FUUAST J Bio 20 I I Jun I; I ( I):5- I7.

8. Akbar A, Sitara U, Khan SA, Muhammad N, Khan MI, Khan YH, et al. Drinking water quality and risk of waterborne diseases in the rural mountainous area of Azad Kashmir Pakistan. Int J Biosci 2013;3(I2): 245-5I.DOI: I0.12692/ijb/3. |2.245-25|.

9. Daud MK, Nafees M, Ali S, Rizwan M, Bajwa RA, Shakoor MB, et al. Drinking water quality status and contamination in Pakistan. BioMed Res Inter 2017;20 17:7908।83. DOI: I0.1I55/2017/7908|83.

10. Mukhopadhyay C, Vishwanath S, Eshwara VK, Shankaranarayana SA, Sagir A. Microbial quality of well water from rural and urban households in Karnataka, India: A cross-sectional study. J infect Public Health 2012 Jun I;5(3):257-62. DOI: 10.1016/j.jiph.2012.03.004.

II. Atherholt TB, Bousenberry RT, Carter GP, Korn LR, Louis JB, Serfes $\mathrm{ME}$, et al. Coliform bacteria in New Jersey domestic wells: influence of geology, laboratory, and method. Ground Wat 2013 Jul;5 I (4):562-74. DOI: $10.11 \mathrm{II} / \mathrm{j} .1745-6584.2012$. 00997.x.

12. Azizullah A, Khattak MN, Richter P, Häder DP. Water pollution in Pakistan and its impact on public health-a review. Env Inter 20II Feb I;37(2):479-97. DOI: 10.1016/ j.envint.2010.10.007.

13. Daud MK, Nafees M, Ali S, Rizwan M, Bajwa RA, Shakoor MB, et al. Drinking water quality status and contamination in Pakistan. Biomed Res Int 2017;2017:7908/83. DOI: 10.1155/2017/7908183.

14. Farooq S, Hashmi I, Qazi IA, Qaiser S, Rasheed S. Monitoring of coliforms and chlorine residual in 
water distribution network of Rawalpindi, Pakistan. Environ Monit Assess 2008 May I; I40(I-3):33947. DOI: $10.1007 / \mathrm{s} 1066 \mathrm{I}-007-$ 9872-2.

I5. Exum NG, Betanzo E, Schwab KJ, Chen TY, Guikema S, Harvey DE. Extreme Precipitation, Public Health Emergencies, and Safe Drinking Water in the USA. Curr Environ Health Rep 2018 Jun;5(2): 305-I5. DOI: 10.1007/s40572-0180200-5.

16. Kirby MA, Nagel CL, Rosa G, lyakaremye L, Zambrano LD, Clasen TF. Faecal contamination of household drinking water in Rwanda: A national cross-sectional study. Sci Total Environ $2016 \mathrm{Nov}$ |5;57|:426-34. DOI: 10.1016/j. scitotenv.2016.06.226.

17. Ahmed W, Gardner T, Toze S. Microbiological quality of roofharvested rainwater and health risks: a review. J Environ Qual 20I I Jan I;40(I):|3-2I. DOI: 10.2134/ jeq 2010.0345 .

18. O'Neill S, Adhikari AR, Gautam MR, Acharya K. Bacterial contamination due to point and nonpoint source pollution in a rapidly growing urban center in an arid region. Urb Water J 20I3 Dec I; I0(6):4I I-2I. DOI: I0. 1080/1573062X.2012.750372.

19. Clarke R, Peyton D, Healy MG, Fenton O, Cummins E. A quantitative microbial risk assessment model for total coliforms and E. coli in surface runoff following application of biosolids to grassland. Environ Pollut 2017 May 1;224:739-50. DOI: 10. I0I6/j.envpol.20I6. 12.025 .

20. Wu J, Yunus M, Islam MS, Emch M. Influence of climate extremes and land use on fecal contamination of shallow tubewells in Bangladesh. Environ Sci Tech 2016 Feb 19;50(5): 2669-76. DOI: 10.102I/acs.est. $5 b 05193$.

21. Hsu TT. Public Health Ecosystem Services and Potential Concerns of Freshwater Wetlands (Doct Dissert The Ohio State University). [Cited on: November 18, 2018]. Available from URL: http://rave.ohiolink.edu/ etdc/view?acc_num =osu 14394874 $0 \mathrm{l}$.

22. Briggs BR, Brodie EL, Tom LM, Dong $H$, Jiang $H$, Huang $Q$, et al. Seasonal patterns in microbial communities inhabiting the hot springs of Tengchong, Yunnan Province, China. Env Microb 2014 Jun;|6(6):|579-9|. DOI: 10. IIII/I462-2920.123।I.

23. $\mathrm{R}$ ahm anian N, Ali SH, Homayoonfard M, Ali NJ, Rehan M, Sadef $Y$, et al. Analysis of physiochemical parameters to evaluate the drinking water quality in the State of Perak, Malaysia. J Chem 2015;2015:716125. DOI: |0.1|55/2015/7|6125.

24. Onuoha SC. The Prevalence of Antibiotic Resistant Diarrhogenic Bacterial Species in Surface Waters, South Eastern Nigeria. Ethio J of Health Sci 201 7;27(4):3 19-30. DOI: 10.4314/ejhs.v27i4.3.

25. Sadik NJ, Uprety S, Nalweyiso A, Kiggundu N, Banadda NE, Shisler JL, et al. Quantification of multiple waterborne pathogens in drinking water, drainage channels, and surface water in Kampala, Uganda, during seasonal variation. Geo Health 2017 Aug; I (6):258-69. DOI: I0.1002/2017GH00008I.

\section{AUTHORS' CONTRIBUTIONS}

Following authors have made substantial contributions to the manuscript as under:

SWS \& SAK: Conception and study design, drafting the manuscript, final approval of the version to be published

MI \& SUUJ: Acquisition, analysis and interpretation of data, critical review, final approval of the version to be published

IS: Analysis and interpretation of data, critical review, final approval of the version to be published

TK: Acquisition, analysis and interpretation of data, drafting the manuscript, final approval of the version to be published

Authors agree to be accountable for all aspects of the work in ensuring that questions related to the accuracy or integrity ofany part of the work are appropriately investigated and resolved.

\begin{tabular}{|c|}
\hline CONFLICT OF INTEREST \\
Authors declared no conflict of interest \\
GRANT SUPPORT AND FINANCIAL DISCLOSURE \\
NIL
\end{tabular}

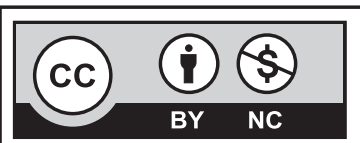

This is an Open Access article distributed under the terms of the Creative Commons Attribution-Non Commercial 2.0 Generic License. 